\title{
TEOLOGI BIBLIKA PERJANJIAN BARU \\ TENTANG HAKIM YANG AKAN DATANG: \\ Kajian Tentang Eskatologi Dalam Perjanjian Baru Dan Implementasinya \\ Dalam Pendidikan Agama Kristen Di Sekolah
}

\author{
Simon Rumante \\ sttjaffraymakassar@yahoo.co.id
}

\begin{abstract}
ABSTRAK
Adapun tujuan yang ingin dicapai dalam penulisan ini adalah: Untuk mengetahui sejauh mana topik eskatologi telah mendapat perhatian yang cukup dalam pembelajaran PAK di sekolah khususnya di SD dan SMP. Menjelaskan bagaimana seharusnya pengimplementasian topik eskatologi dalam pembelajaran PAK di sekolah khususnya di SD dan SMP.

Metode penelitian yang digunakan dalam rangka penulisan ini adalah penelitian pustaka (Library Research) yakni pengumpulan data dari buku-buku seperti yang tercantum dalam Daftar Pustaka.

Berdasarkan pemaparan singkat di atas, maka penulis menyimpulan bahwa: Pertama, Pengajaran tentang eskatologi dalam PAK di sekolah khususnya di SD dan SMP sangat penting tetapi masih sangat kurang mendapat perhatian. Hal itu jelas bila kita memerhatikan kurikulum PAK yang tidak mencantumkan topik eskatologi sebagai salah satu materi pokok. Kedua, Dalam rangka pengimplementasian topik eskatologi dalam pengajaran PAK di sekolah, maka hal-hal yang harus ditekankan adalah nasihat untuk berjaga-jaga, bekerja dengan setia, pelita kita harus tetap menyala dan mengembangkan talenta yang diberikan oleh Tuhan.
\end{abstract}

Kata Kunci: Teologi Biblika dan Hakim Yang Akan Datang

\section{PENDAHULUAN}

\section{Latar Belakang Masalah}

Pelajaran tentang kedatangan Tuhan Yesus yang kedua kali (eskatologi), adalah merupakan salah satu dasar dari iman Kristen, sehingga pelajaran ini perlu diketahui, diajarkan dan diimani oleh setiap umat Tuhan termasuk kepada murid-murid di sekolah. Namun karena banyaknya pendapat dan tafsiran mengenai pelajaran kedatangan Tuhan Yesus kedua 
kali, maka sangatlah perlu mengetengahkan pelajaran ini secara benar dan tepat seperti apa yang dikatakan oleh Firman Allah.

Kekurangpahaman dalam penguasaan pelajaran tentang kedatangan Tuhan Yesus kedua kali bisa menyebabkan penafsiran yang menyimpang bahkan bertolak belakang dengan Firman Allah itu sendiri. Tidak sedikit kesalahan dalam penafsiran dan penyajian pelajaran tentang kedatangan Tuhan Yesus kedua kali, bukannya membangkitkan gairah, semangat dan harapan, damai dan sejahtera untuk menyambut kedatangan Yesus yang kedua kali, sebaliknya justru mendatangkan perasaan takut, gelisah, bingung dan penyesatan. Contoh, pada awal tahun 1992, telah berkembang pengajaran yang mengajarkan bahwa pada tanggal 28 Oktober 1992 Tuhan Yesus akan datang kedua kali. Namun kenyataannya? Sampai sekarang pun Tuhan Yesus belum datang. Akibatnya adalah: Umat Tuhan menjadi bingung, banyak umat Tuhan menjadi gelisah, bahkan ada yang sampai disesatkan, dan lain-lain.

Topik tentang eskatologi sangat penting untuk diajarkan kepada siswa di sekolah agar mereka dapat mempersiapkan diri dengan sebaikbaiknya untuk menyambut kedatangan Tuhan Yesus yang kedua kali. Dalam pengajaran Pendidikan Agama Kristen (PAK) di sekolah, seharusnya topik atau pelajaran ini mendapat perhatian dan alokasi waktu yang cukup. Melalui topik atau pelajaran ini diharapkan dapat memperkuat keimanan siswa, menolong siswa untuk merubah sikap yang tidak sesuai dengan kehendak Allah dan menanamkan dalam diri siswa bahwa kelak ketika Tuhan Yesus datang untuk yang kedua kalinya, Ia akan mengadili manusia. Namun kenyataannya tidak seperti yang seharusnya. Pembelajaran tentang eskatologi hanya disinggung sepintas lalu ketika mengajarkan topik/ materi yang ada kaitannya dengan eskatologi, misalnya kenaikan Tuhan Yesus ke sorga. Tidak ada topik khusus eskatologi dalam pengajaran PAK di sekolah. Berbeda dengan saudara-saudara kita di kalangan Muslim, di tingkat Sekolah Dasar saja, topik eskatologi yang mereka kenal dengan istilah "hari kiamat atau hari kemudian" benar-benar mendapat perhatian yang cukup bahkan diajarkan antara dua sampai tiga kali yakni pada kelas yang berbeda.

Berdasarkan latar belakang masalah di atas, maka penulis terdorong untuk mengkaji sejauh mana pengimplementasian topik eskatologi Perjanjian Baru dalam PAK sekolah, dengan judul: Hakim yang akan datang: Kajian tentang eskatologi dalam Perjanjian Baru dan implementasinya dalam PAK di sekolah. Penulis hanya akan membatasi pengimplementasian topik ini pada jenjang pendidikan dasar yakni Sekolah Dasar (SD) dan Sekolah Menengah Pertama (SMP).

\section{Rumusan Masalah}

Bertitik tolak dari latar belakang masalah di atas, maka rumusan masalah yang dikaji dalam tulisan ini adalah: Pertama, Sejauh mana topik 
eskatologi telah mendapat perhatian yang cukup dalam pembelajaran PAK di sekolah khususnya di SD dan SMP?. Kedua, Bagaimana seharusnya pengimplementasian topik eskatologi dalam pembelajaran PAK di sekolah khususnya di SD dan SMP?

\section{Tujuan Penulisan}

Adapun tujuan yang ingin dicapai dalam penulisan ini adalah: Pertama, Untuk mengetahui sejauh mana topik eskatologi telah mendapat perhatian yang cukup dalam pembelajaran PAK di sekolah khususnya di SD dan SMP. Kedua, Menjelaskan bagaimana seharusnya pengimplementasian topik eskatologi dalam pembelajaran PAK di sekolah khususnya di SD dan SMP.

\section{Metode Penelitian}

Metode penelitian yang digunakan dalam rangka penulisan ini adalah penelitian pustaka (Library Research) yakni pengumpulan data dari bukubuku seperti yang tercantum dalam Daftar Pustaka.

\section{KAJIAN TEORITIS}

\section{Pengertian Eskatologi}

Kata Eskatologi, datang dari kata "ESKATON" yang mengandung arti "Yang Akhir", yang dimaksud "Yang Akhir" di sini tentunya mengacu kepada segala peristiwa yang terjadi menjelang, pada saat dan setelah kedatanganNya kedua kali. Dengan demikian, eskatologi adalah ilmu yang mempelajari segala sesuatu yang terjadi menjelang, maupun saat bahkan setelah kedatangan Yesus kedua kali. ${ }^{1}$

\section{Ajaran Eskatologi dalam agama suku, Islam dan Kristen}

Ajaran eskatologi tidak hanya diajarkan dalam agama Kristen. Di Indonesia, semua agama termasuk agama suku mengajarkan tentang eskatologi dengan ajarannya masing-masing. Khusus dalam tulisan ini, hanya akan memaparkan ajaran eskatologi dalam agama suku, Islam dan Kristen.

\section{Agama Suku}

Menurut Harun Hadiwijono, Agama Suku Murba di Indonesia mengajarkan bahwa di luar dunia manusia ini ada dunia orang mati, yaitu tempat para orang yang telah mati. Tempat ini ada yang digambarkannya sebagai tempat nenek moyangnya, ada yang digambarkan sebagai tempat

1 Eskatologi-2, sarapanpagi.com; diakses 29 Maret 2010; tersedia di http://www.sarapanpagi.org/ eskatologi-vfll.html. 
para dewa, yaitu sorga. Orang yang mati kembali kepada asalnya, tempat nenek moyang itu atau sorga. ${ }^{2}$

\section{Agama suku}

Agama suku Toraja (Aluk Todolo), juga mengajarkan bahwa semua arwah orang yang sudah meninggal dunia menuju ke satu tempat peristirahatan yang bernama Puya. Puya adalah dunia jiwa. Letaknya dibayangkan berada di sebelah Selatan langit horison. Apabila seorang meninggal dunia jiwanya keluar dari jasad tubuhnya dan bersiap memasuki fase kehidupan baru di alam Puya. ${ }^{3}$

\section{Agama Islam}

Agama Islam mengajarkan tentang sorga, yang akan mengakhiri perjalanan dunia ini sebagai berikut:

"Orang-orang mati sekarang ini masih berada di dalam alam barzakh sampai pada akhir zaman. Sesudah diadakan penghakiman pada akhir zaman, para manusia dengan melalui syirat al mustaqim menuju ke sorga. Hanya orang yang berimanlah yang akan dapat berhasil melalui syirat atau jembatan itu, sedangkan lainnya akan terjatuh ke dalam jurang neraka yang ada di bawah syirat itu. Dunia yang kita diami sekarang ini akan berakhir, para orang beriman dipindahkan ke sorga. ${ }^{4}$ Alam barzakh adalah alam yang berada di antara alam dunia dan alam akhirat. Di sini para jiwa manusia belum menerima balasan amalnya. Mereka baru merasakan tanda-tanda dan gejala-gejala penagihan atau pemberian jasa dari apa yang dilakukan ketika hidupnya. Sorga dan neraka baru ditentukan kelak pada akhir zaman."

\section{Agama Kristen}

Eskatologi menurut ajaran Kristen terkait dengan pemenuhan janji Allah yaitu keselamatan yang sempurna di dalam Kristus. Harun hadiwijono menyatakan bahwa:

"Menurut Alkitab keselamatan pada zaman akhir ini memiliki dua segi, yaitu bahwa pada zaman akhir ini telah ada keselamatan, akan tetapi di lain pihak dikatakan juga bahwa keselamatan masih di depan kita atau belum ada. Maksudnya adalah keselamatan yang telah diberikan oleh Allah kepada orang beriman, baru "untuk sementara waktu", belum sempurna. Apa yang telah ada sekarang ini belum sempurna. Akan tetapi apa yang telah ada itu menjadi jaminan atau garansi, bahwa semua yang sempurna akan dianugerahkan juga."

\footnotetext{
${ }^{2}$ Harun Hadiwijono, Iman Kristen (Jakarta: BPK Gunung Mulia, 2007) Cet. ke-18, 471

${ }^{3}$ J. K. Palinggi', wawancara oleh penulis, Makassar, 30 Maret 2010

${ }^{4}$ Harun Hadiwijono, op. cit., 472

${ }^{5}$ Ibid., 475

${ }^{6}$ Ibid., 473
} 
Dengan demikian dapat dikatakan bahwa hidup orang beriman bukan diarahkan kepada hidup di dunia ini, melainkan kepada apa yang akan datang. Pengharapan orang beriman kepada Kristus harus diarahkan ke masa depan yakni akhir zaman, zaman penuaian untuk memisahkan yang baik dan yang jahat (Mat. 13:39-40,49; 24:3; 28:20). Dalam Ef. 1:10, zaman itu disebut zaman kegenapan waktu untuk mempersatukan segala sesuatu di dalam Kristus sebagai Kepala, baik yang di sorga maupun yang di bumi. Oleh karena itu, dalam 1 dan 2 Tesalonika serta 1 Korintus 15, kita dinasihatkan oleh rasul Paulus agar pengharapan kita orang beriman diarahkan kepada akhir zaman.

Lebih lanjut Harun Hadiwijono menyatakan bahwa:

"Hidup manusia sekarang ini (zaman akhir) dihubungkan dengan akhir zaman. Pada zaman akhir, kita diberi ciri dari keselamatan yang telah dikaruniakan kepada kita, tetapi yang belum secara sempurna menjadi milik kita. Sekalipun kita telah diselamatkan, namun kita masih harus berusaha untuk memegangnya (Fil. 3:12), berusaha dengan bersungguh-sungguh di dalam peperangan iman untuk mencapai hidup kekal, yang menjadi tujuan panggilan kita (1 Tim. 6:12)."7

Kedatangan Kristus yang kedua kali adalah kedatangan untuk menghakimi orang yang hidup dan yang mati. Karena itu, kedatangan Kristus yang kedua kali bukanlah suatu kejadian yang tiada sangkut pautnya dengan hidup sehari-hari pada zaman sekarang ini. Pada waktu itu segala sesuatu di dalam dunia ini akan dibuka tutupnya, akan dibuka kedoknya, di hadapan Allah. ${ }^{8}$

Menurut H. L. Willmington, maksud kedatangan Kristus yang kedua kali adalah :

1. Untuk mengalahkan antikristus beserta bangsa-bangsa di dunia yang berkumpul di Harmagedon (bnd. Wahyu 19:17-21).

2. Untuk mengumpulkan kembali, memperbaharui dan memulihkan umat Israel yang setia. (Yes. 43:5,6; Yer. 24:6; Yeh. 36:28; Amos 9:14,15; Mikha 7:18, 19; Mat. 24:31).

3. Untuk menghakimi dan menghukum umat Israel yang tidak setia (Roma 9:6; 11:26; I Tes. 2:25,16; Yeh. 11:21 dan 20:38).

4. Untuk memisahkan domba dan kambing (Mat. 25:31-46)

5. Untuk mengikat iblis (Roma 16:20; Wahyu 20:1-3)

6. Untuk membangkitkan orang-orang kudus dari zaman Perjanjian Lama dan dari masa siksaan (Ayub 19:25,26; Mz. 49:16; Yes. 25:8; 26:19; Dan. 12:2, Hosea 13:14; Yoh. 5:28-29; Ibr. 11:35; dan Wahyu 20:4,5).

7. Untuk menghakimi malakat-malaikat yang jatuh (I Kor. 6:3; Luk. 8:30-31; Mark. 1:23,24; dan Ef. 6:112). ${ }^{9}$

\footnotetext{
${ }^{7} \mathrm{Ibid}, 474$

${ }^{8}$ Harun Hadiwijono, Inilah Sahadatku (Jakarta: BPK Gunung Mulia, 1995), 115-116.

9 H. L. Willmington, Eskatologi (Malang: Gandum Mas, 1997), 265-282.
} 


\section{Beberapa Pandangan Pokok tentang Eskatologi}

Pada awal abad ke-2l ini, ilmu PB mulai melihat secara baru bahwa pekabaran Yesus dan jemaat mula-mula adalah bersifat eskatologis. Berikut ini akan dipaparkan pandangan para teolog mengenai eskatologi.

\section{J. Weiss}

Menurut J. Weiss, Yesus menantikan perubahan zaman yang akan berlangsung dengan segera sebagai hasil kegiatan Allah yang baru. Kerajaan Allah bukanlah suatu keadaan sempurna, yang lama-kelamaan dicapai melalui perkembangan dunia yang berlangsung terus. Kerajaan Allah itu akan datang dengan tiba-tiba dari seberang melalui suatu bencana semesta alam yang mengerikan. ${ }^{10}$

\section{A. Schweitzer}

A. Schweitzer menekankan sifat futuris pekabaran Yesus. Dalam hal eskatologi, beliau menyatakan bahwa:

"Segenap pikiran Yesus terarah pada kedatangan Kerajaan Allah dengan segera. Yesus sendiri akan sempat mengalaminya. Tetapi harapan itu tidak terkabul. Penantian-nantian apokaliptis terbentuknya Kerajaan Allah tidak tergenapi. Akibatnya besar! Karena seluruh pekabaran Yesus secara konsekuen bersifat eskatologis, maka secara konsekuen pula harus diambil kesimpulan: Yesus keliru, pengharapan dan sistem pengajaran-Nya tidak tepat. Memang kemudian, Schweitzer tidak benar-benar konsekuen, sebab masih mempertahankan beberapa segi wejangan etis Yesus yang intinya ialah "pengharapan terhadap hidup."

\section{H. Dodd}

Berbeda dengan pendapat Schweitzer, C. H. Dodd menekankan secara berat sebelah realized eschatology. Eskatologi Yesus, Paulus dan Yohanes bersifat presentis. Kerajaan Allah, keselamatan, kehidupan kekal sudah terwujud kini dan disini. Jemaat mengharapkan tibanya akhir zaman sesudah kematian dan kebangkitan Yesus Kristus. ${ }^{72}$

\section{R. Bultmann}

Pandangan R. Bultmann dan sebagian murid-muridnya mengenai eskatologi berkaitan dengan pengertian tentang sejarah. Sejarah tidak hanya diartikan sebagai suatu rentetan zaman yang berturut-turut. Sejarah lebih mengartikan kesejarahan eksistensi manusia. Yang dimaksud ialah sejarah hidup yang dialami setiap manusia dan yang mengandung kedua kemungkinan, yaitu dapat atau tidak menemui kepribadian yang sejati. Dalam kaitannya dengan eskatologi, Bultmann berpendapat bahwa orang percaya hidup dari dan di dalam Kristus. Dan karena Kristus adalah

10 Bnd. Ulrich Beyer, Garis-Garis Besar Eskatologi Dalam Perjanjian Baru (Jakarta: BPK Gunung Mulia, 2001), 1.

11 Ibid.

${ }^{12}$ Ibid., 2 
"penyudah sejarah" (Roma 10:4), maka orang yang hidup "dalam Kristus" sudah menghadapi akhir sejarah dan telah memasuki eskaton. ${ }^{13}$

\section{O. Cullmann.}

O. Cullmann mengembangkan pengertiannya yang temporal tentang eskatologi PB dengan memperdebatkan secara kritis pandangan-pandangan tersebut di atas. Cullmann menyatakan bahwa:

"Eskatologi sudah genap realisasinya, belum kelihatan kesempurnaannya. Ibarat suatu perang, pertempuran yang menentukan sudah berlalu; "victory day", yaitu hari kemenangan, sudah tiba, tetapi gencatan senjata belum dilaksanakan oleh kedua belah pihak yang telah berperang itu, sehingga disana sini masih berlangsung beberapa perkelahian kecil. Hari kemenangan sudah tiba dengan kedatangan serta karya Yesus Kristus dan sekarang kita sudah ditebus. Tetapi, pada pihak lain, dosa masih berpengaruh, maut belum ditiadakan, dan seluruh dunia tampaknya memang belum dikuasai oleh kemenangan Tuhan Yesus Kristus." ${ }^{14}$

\section{Kapan mulainya Eskatologi?}

Menurut Harun Hadiwijono, eskatologi itu mulai dengan kelahiran Tuhan Yesus Kristus hingga sekarang dan seterusnya. ${ }^{15}$ Agak senada dengan itu, Ulrich Beyer menyatakan bahwa dengan kematian dan kebangkitan Yesus sudah berlangsung kejadian eskatologis yang menentukan. ${ }^{16}$ Sedangkan menurut ajaran aliran-aliran Pantekosta, eskatologi itu mulai ketika kedatangan Kristus kembali yang pertama dan memerintah di bumi ini selama seribu tahun. ${ }^{17}$

\section{Pemahaman tentang Chiliasme dan Millenialisme}

Para kaum Khiliast dan Millenialis mengajarkan bahwa:

"Kelak pada akhir zaman Kristus akan datang kembali dua kali. Kedatangan-Nya kembali yang pertama diperlukan untuk memerintah sebagai Raja atas dunia ini, bersama-sama dengan para orang beriman selama seribu tahun. Selama seribu tahun ini Iblis diikat dengan rantai dan dilemparkan ke dalam jurang maut. Akan tetapi pada akhir seribu tahun itu Iblis dilepaskan dari ikatan rantainya lalu menyesatkan segala bangsa, guna memerangi para orang beriman. Tuhan Yesus yang telah memerintah seribu tahun tadi, naik ke sorga lagi, sekarang datang kembali untuk kedua kalinya, guna menghakimi segala manusia. ${ }^{9}$

\footnotetext{
13 Ibid.

${ }^{14}$ Ibid., 3-4

${ }^{15}$ Harun Hadiwijono, Iman Kristen, op. cit., 473

${ }^{16}$ Ulrich Beyer, op.cit., 24

${ }^{17}$ Harun Hadiwijono, Iman Kristen, op. cit., 490

${ }^{18}$ Ibid., 491
} 
Ajaran ini didasarkan atas penafsiran secara harafiah Wahyu 20. Atas ajaran para kaum Khiliast ini, Harun Hadiwijono berkeyakinan bahwa:

"Pandangan yang demikian tidak sesuai dengan gagasan yang terkandung dalam kitab Wahyu sendiri. Menurutnya, suatu wahyu dalam Alkitab, tidak pernah memberikan laporan mengenai urutanurutan peristiwa yang akan terjadi. Kitab Wahyu adalah suatu pernyataan atau suatu pengambilan tutup yang menutupi keselamatan yang dikaruniakan di dalam Kristus. .... Kitab wahyu bukan diberikan untuk memberi kepuasan kepada keinginan kita untuk mengetahui halhal yang akan terjadi. Segala gambaran yang diberikan di dalam kitab Wahyu adalah "gambaran wahyu" .... bahwa para orang beriman sekarang ini sudah turut memerintah bersama-sama dengan Kristus .... ${ }^{19}$

Senada dengan itu, H. L. Willmington mengemukakan bahwa "banyak orang telah menyatakan bahwa karena angka ini hanya terdapat dalam satu bagian Perjanjian Baru, maka orang tidak dapat memastikan bahwa masa seribu tahun akan benar-benar menjadi kenyataan. Untuk menekankan maksud tersebut, mereka mengacu pada 2 Petrus 3:8 : “ .... di hadapan Tuhan satu hari sama seperti seribu tahun dan seribu tahun sama seperti satu hari." 20

Maksud dari kerajaan seribu tahun adalah :

1. Untuk membalas perbuatan orang-orang kudus Allah (Mz. 58:12; Amsal 11:18; Yes. 40:10; Mat. 16:27; 35:34; Kol. 3:24 dan Wahyu 22:12).

2. Untuk menjawab doa contoh yang sering dipanjatkan (Luk. 11:1-4 dan Mat. 6:9-13).

3. Untuk menebus ciptaan (Roma 8:19-22).

4. Untuk memenuhi tiga perjanjian penting di dalam Perjanjian Lama yaitu janji Allah kepada Abraham, perjanjian yang menyangkut Daud dan perjanjian baru.

5. Untuk membuktikan satu hal yaitu bagaimana pun lingkungan atau keturunan seseorang, jika terpisah dari kasih karunia Allah, manusia pasti akan gagal (Kej. 3; 6; 1l; Kel. 1; Mat.27; I Tim. 4; Wahyu 19 dan Wahyu 20).

6. Untuk menggenapi pokok utama dari nubuat dalam Alkitab (I Pet. 1:1). ${ }^{21}$

\section{Hubungan Eskatologi dengan konsep kiamat}

Menurut ajaran agama Suku Murba, orang yang telah mati, jiwanya berada di dalam "sorga antara", sebagai tempat kediaman sementara. Pada perayaan penyempurnaan jiwa-jiwa tadi dibimbing masuk ke dalam "dunia nenek moyang” dengan suatu upacara tertentu. Setelah jiwa itu dimandikan

\footnotetext{
${ }^{19}$ Ibid

${ }^{20}$ H. L. Willmington. op. cit., 285

${ }^{21}$ Ibid., hlm. 288-29l
} 
di dalam kolam air hidup dan mendapat hidup yang baru, jiwa itu diperkenankan hidup di dalam dunia nenek moyang. ${ }^{22}$

Menurut Agama Suku Toraja (Aluk Todolo), bila orang meninggal dan sang jiwa ini menghadap penguasa Puya, ia akan ditanya sudah berapa jauh upacara pemakamannya dilaksanakan dengan baik sesuai dengan tingkatan kemungkinan upacara yang tersedia. Kalau ternyata upacaranya belum selesai dilaksanakan dengan baik maka arwah itu tidak diperbolehkan masuk Puya, harus kembali ke dunia semula. Menurut kepercayaan Aluk Todolo, makhluk halus yang sering mengganggu masyarakat adalah jiwa orang mati yang belum diperkenankan masuk Puya. Karena itu, orang yang meninggal harus diupacarakan dengan baik sesuai dengan tingkatan atau strata sosialnya. Hewan (kerbau dan Babi) yang dikurbankan dan pesta yang meriah dianggap sebagai bekal menuju Puya. ${ }^{23}$

Agama Islam mengajarkan, bahwa Kristus akan datang kembali. Sebelum hari kiamat akan datanglah al Djalal yang akan memperdayakan manusia di dalam dunia ini. Ketika telah banyak kekacauan dan fitnah yang dilakukan al Djalal itu turunlah nabi Isa a.s. Ia membunuh al Djalal dan menolong umat yang sedang kacau itu. Nabi Isa mematahkan semua salib kaum Nasrani dan menunjukkan kebenaran yang sejati. Ia mengembalikan semua umat kepada agama Islam. ${ }^{24}$

Menurut ajaran Kristen yang didasarkan pada Alkitab, kedatangan Kristus biasa disebut "kedatangan-Nya yang kedua kali" untuk membedakan kedatangan-Nya pada akhir zaman dengan kedatangan-Nya yang pertama, ketika Kristus lahir di Betlehem. “... Ketika Ia datang di dalam daging atau menjadi manusia masih banyak hal yang dirahasiakan, sehingga banyak orang yang tidak tahu siapa sebenarnya Dia itu. Akan tetapi kedatangan-Nya yang kedua kali itu akan terjadi di dalam kemuliaan. Segala rahasia pada waktu itu akan terbuka, dan menyempurnakan kedatangan-Nya yang pertama." ${ }^{25}$

\section{Hal-hal yang terjadi sesudah kiamat}

Menyangkut hal-hal yang akan terjadi sesudah kiamat, ajaran Agama Islam menyatakan bahwa:

"Pada hari kiamat, setelah orang-orang dibangkitkan dan dikumpulkan di suatu tempat yang disebut masyar, mereka lalu diadili. Sesudah itu orang-orang harus menempuh syirat atau jembatan yang menghubungkan dunia ini dengan sorga, dan yang melintang di atas jurang berapi, yaitu neraka. Syirat ini amat halus, lebih halus daripada rambut dibelah menjadi tujuh, lebih tajam daripada pedang. Kecepatan

${ }^{22}$ Harun Hadiwijono, Iman Kristen, op. cit., 475

23 J. K. Palinggi', wawancara oleh penulis, Makassar, 30 Maret 2010

24 Op.cit., 479

${ }^{25}$ Ibid. 
melaluinya ditentukan oleh amal-amal seseorang. Sementara orang-orang melalui syirat, nabi Muhammad mendoakan umatnya supaya mereka dapat lepas daripada hukuman. Siapa yang selamat melintasi syirat itu, ia masuk ke sorga. ${ }^{26}$

Menurut ajaran Alkitab, Kedatangan Tuhan Yesus yang kedua kalinya, pertama-tama dimaksudkan bagi keselamatan orang beriman. Orang-orang yang beriman pada hari kedatangan-Nya itu akan dibangkitkan dan akan dimuliakan bersama-sama dengan orang beriman yang masih hidup. ${ }^{27}$

Pernyataan kitab suci tentang keadaan orang sesudah mati ialah:

1. Segera sesudah mati, maka orang diadili. Meskipun pengadilan yang terbuka, yang kelihatan oleh segala orang dan seluruh dunia, masih akan terjadi pada kedatangan kembali dari Yesus Kristus, tetapi pengadilan yang pertama ini sudah menentukan segala sesuatu (Ibr. 9:27).

2. Sesudah mati tidak ada lagi kemungkinan untuk bertobat.

3. Orang percaya segera dijadikan sempurna dan oleh karena itu dinaikkan ke sorga. Tidak usahlah ia memasuki api penyucian (RK) (Luk. 23:43). ${ }^{28}$

Kristus akan mengaruniakan langit yang baru dan bumi yang baru atau Yerusalem baru. Yerusalem baru berarti umat Allah menjadi satu dengan Tuhannya. Orang-orang percaya telah nyata-nyata menjadi anak Allah dan menghadap kepada Bapanya. ${ }^{29}$

Perbedaan antara harapan orang Kristen dengan harapan agamaagama lain khususnya orang Islam setelah akhir zaman adalah bahwa jikalau menurut agama Islam setelah akhir dunia ini akan menyusul suatu kehidupan di sorga, sedangkan harapan Kristen, menurut Alkitab, menantinantikan dunia yang baru, dimana terdapat kebenaran (2 Ptr. 3:13). ${ }^{30}$

\footnotetext{
${ }^{26}$ Ibid. 499

27 Ibid. 493

${ }^{28}$ R. Soedarmo, Ikhtisar Dogmatika (Jakarta: BPK Gunung Mulia, 2001), 252

29 Ibid., 258

30 Harun Hadiwijono, Iman Kristen, op. cit., 474
} 


\section{ESKATOLOGI DAN IMPELEMENTASINYA DALAM PAK DI SEKOLAH}

\section{Hakikat dan Tujuan PAK}

Pendidikan Agama Kristen pada prinsipnya berorientasi pada pengertian kekristenan, yaitu pendidikan yang berpusat pada Kristus. B. Samuel Sidjabat mengutip pandangan Robert W. Pazmino memberikan definisi tentang pendidikan Agama Kristen sebagai berikut:

"Pendidikan Kristen merupakan usaha bersahaja dan sistematis, ditopang oleh upaya rohani dan manusiawi untuk mentransmisikan pengetahuan, nilai-nilai, sikap-sikap, keterampilan-keterampilan dan tingkah laku yang bersesuaian/konsisten dengan iman Kristen; mengupayakan perubahan, pembaharuan dan reformasi pribadi-pribadi, kelompok bahkan struktur oleh kuasa Roh Kudus, sehingga peserta didik hidup sesuai dengan kehendak Allah sebagaimana dinyatakan oleh Alkitab, terutama dalam Yesus Kristus." ${ }^{31}$

Hakikat PAK di atas merupakan pengembangan dari arti PAK yang dirumuskan oleh E. G. Homrighausen dan I. H. Enklaar pada Konferensi PAK di Sukabumi pada tahun 1955 sebagai berikut:

"Inilah arti sedalam-dalamnya dari PAK, bahwa dengan menerima pendidikan itu, segala pelajar, muda dan tua, memasuki persekutuan iman yang hidup dengan Tuhan sendiri, dan oleh dan dalam Dia mereka terhisab pula pada persekutuan jemaat-Nya yang mengakui dan mempermuliakan Nama-Nya di segala waktu dan tempat." ${ }^{32}$

Jadi, PAK di sekolah pada hakikatnya adalah pendidikan yang diberikan secara terencana, sistematis dan kontinu kepada setiap peserta didik agar memahami kasih dan karya Allah dalam hidupnya dan membantu peserta didik dalam mentransformasikan nilai-nilai Kristiani dalam kehidupan sehari-hari.

Konferensi Kurikulum I PAK yang diselenggarakan oleh KOMPAK DGI di Sukabumi, 12 Juni s/d 14 Juli 1963, merumuskan tujuan PAK sebagai berikut:

"Mengajak, membantu, menghantar seseorang untuk mengenal akan kasih Allah yang nyata dalam Yesus Kristus, sehingga dengan pimpinan Roh Kudus, ia datang ke dalam satu persekutuan hidup pribadi dengan Tuhan. Hal ini dinyatatakan dalam kasihnya kepada Allah dan sesamanya manusia yang dihayatinya dalam hidupnya sehari-hari, baik

${ }^{31}$ B. Samuel Sidjabat, Strategi Pendidikan Kristen (Yogyakarta: Andi Offset, 1994), 10.

32 E. G. Homrighausen dan I. H. Enklaar, Pendidikan Agama Kristen (Jakarta: BPK Gunung Mulia, 2004), 26. 
dengan kata-kata, maupun dengan perbuatan selaku anggota Tubuh Kristus." 33

Rumusan di atas kemudian berubah sebagaimana yang dirumuskan dalam Seminar PAK di Jakarta, pada tanggal 22 - 25 Februari 1988 yang diselenggarakan oleh PGI (Persekutuan Gereja-gereja di Indonesia) dalam kerjasama dengan MPPK (Majelis Pusat Pendidikan Kristen di Indonesia), PERSETIA (Perhimpunan Sekolah-sekolah Tinggi Theologia di Indonesia) dan BK-PTKI (Badan Kerjasama Perguruan Tinggi Kristen di Indonesia) sebagai berikut:

"PAK sebagai tugas panggilan gereja adalah usaha untuk menumbuhkan dan mengembangkan kemampuan peserta didik agar dengan pertolongan Roh Kudus dapat memahami dan menghayati Kasih Allah dalam Yesus Kristus, yang dinyatakannya dalam kehidupan sehari-hari, terhadap sesama dan lingkungan hidupnya." 34

Kemudian, Oditha Hutabarat dan Wiwik Estiawan merumuskan tujuan PAK di sekolah dengan sedikit memodifikasi tujuan PAK di atas sebagai berikut:

"PAK adalah usaha yang dilakukan secara terencana dan kontinu dalam rangka mengembangkan kemampuan pada siswa agar dengan pertolongan Roh Kudus dapat memahami dan menghayati kasih Allah di dalam Yesus Kristus yang dinyatakannya dalam kehidupan sehari-hari, terhadap sesama dan lingkungannya." 35

Berdasarkan tujuan PAK di atas, dapat ditarik tiga inti tujuan PAK di sekolah sebagai berikut:

1. Memperkenalkan Allah Bapa, Putera dan Roh Kudus dan karya-karyaNya.

2. Menghasilkan manusia Indonesia yang mampu menghayati imannya secara bertanggung jawab di tengah masyarakat yang pluralistik.

3. Menanamkan pemahaman tentang Allah dan Karya-Nya kepada siswa, sehingga mampu memahami dan menghayati karya Allah dalam hidup manusia. ${ }^{36}$

\section{Eskatologi dalam kurikulum PAK di sekolah}

Seperti yang telah dikemukakan pada bagian pendahuluan bahwa pengajaran tentang eskatologi dalam PAK di sekolah khususnya di SD dan SMP sangat penting tetapi masih kurang mendapat perhatian. Mungkin penyebabnya adalah topik eskatologi tidak tercantum secara tersurat dalam

\footnotetext{
${ }^{33}$ Jedida T. Posumah-Santosa, Pendidikan Agama Kristen di Sekolah, dalam Andar Ismail (Peny.), Ajarlah Mereka Melakukan (Jakarta: BPK Gunung Mulia, 2004), 158.

${ }^{34}$ Ibid., 157.

${ }^{35}$ Oditha Hutabarat dan Wiwik Estiawan, Kurikulum Pendidikan Agama Kristen Berbasis Kompetensi Sekolah Dasar (Jakarta: Bagian Proyek Peningkatan Wawasan Kependidikan Guru Agama Ditjen Dikdasmen Depdiknas, 2003), 3.

${ }^{36}$ Ibid. $3-4$.
} 
kurikulum. Jika kita memerhatikan dengan seksama kurikulum PAK baik di tingkat SD maupun SMP, mulai dari kurikulum 1994 yang dikenal dengan kurikulum CBSA sampai suplemen kurikulum 1999, topik eskatologi tidak dicantumkan secara khusus dalam materi pengajaran. Demikian halnya dalam kurikulum 2004 yang dikenal dengan sebutan Kurikulum Berbasis Kompetensi (KBK) sampai kurikulum 2006 yang dikenal dengan sebutan Kurikulum Tingkat Satuan Pendidikan (KTSP), topik eskatologi juga tidak tercantum dalam Standar Kompetensi (SK) maupun dalam Kompetensi Dasar (KD).

Namun demikian, hendaknya guru PAK jeli dan tanggap melihat peluang untuk memasukkan topik eskatologi ini dalam pengajaran PAK di sekolah. Alasannya adalah Kurikulum Tingkat Satuan Pendidikan (KTSP) memberi peluang bagi guru untuk mendesain materi pengajaran sedemikian rupa karena KTSP disusun dan dilaksanakan oleh masing-masing satuan pendidikan (sekolah) berdasarkan konteks dan karakteristik masingmasing dengan tetap berpedoman pada Standar Isi, yang dijabarkan ke dalam Standar Kompetensi (SK) dan Kompetensi Dasar (KD) yang telah ditetapkan oleh Badan Nasional Standar Pendidikan (BNSP). Penyusunan materi pengajaran, di samping mengacu pada SK dan KD tersebut, juga harus mempertimbangkan keunikan peserta didik, kontekstualisasi serta stakeholder sekolah. Karena itu, ke depan diharapkan bahwa topik eskatologi dijadikan sebagai salah satu materi pokok dengan menyisipkan topik tersebut pada SK dan KD yang terkait misalnya pada SK dan KD tentang karya penyelamatan Tuhan Yesus, sehingga topik ini benar-benar dapat termuat dalam kurikulum dan diajarkan secara terencana dan terinci dalam PAK di sekolah dengan alokasi waktu yang cukup.

\section{Pengajaran tentang Eskatologi dalam PAK di sekolah}

Sekalipun kita tidak mengetahui waktu yang tepat Tuhan Yesus datang kembali, namun kita perlu memiliki sikap yang benar dalam menyambut kedatanganNya. Hal ini perlu ditegaskan dalam pengajaran tentang eskatologi dalam PAK karena tidak sedikit orang yang mengambil sikap yang salah. Kesalahan yang dilakukan misalnya oleh Pdt. Mangapin dan jemaatnya beberapa tahun lalu, bukanlah yang pertama kali. Sebenarnya, sejarah gereja telah berulang kali menyaksikan adanya kesalahan yang sama di seluruh dunia dilakukan oleh orang-orang yang sesat dalam ketulusannya. Itulah sebabnya dalam khotbah-Nya tentang akhir zaman, Tuhan Yesus tidak lupa menegaskan sikap yang benar yang harus dilakukan oleh umatNya dalam menanti kedatangan-Nya.

Dengan mengacu pada pengajaran Tuhan Yesus sendiri, maka dalam pengajaran PAK di sekolah tentang topik eskatologi, ada beberapa hal yang perlu ditekankan yaitu:

1. Nasihat untuk berjaga-jaga. Kita harus berjaga-jaga karena sebagaimana disebut di atas, kedatangan-Nya kelak tidak terduga sebelumnya. Segala 
sesuatu berjalan secara rutin, sebagaimana kehidupan normal sehari-hari berlangsung. Tuhan Yesus bersabda: "Sebab sebagaimana mereka pada zaman sebelum air bah itu makan dan minum, kawin dan mengawinkan, sampai kepada hari Nuh masuk ke dalam bahtera, dan mereka tidak tahu akan sesuatu, demikian pulalah halnya kelak pada kedatangan Anak Manusia" (Mat.24:38,39).

2. Bekerja dengan setia. Tuhan tidak menginginkan kita menanti dengan pasif, tetapi harus aktif dengan melakukan segala tugas yang telah dipercayakan-Nya kepada kita, termasuk tugas untuk belajar sebagai seorang siswa. Tidak ada tugas dan pekerjaan yang kurang mulia bila kita kerjakan dalam Dia. Untuk itulah Tuhan Yesus memberikan perumpamaan tentang hamba yang setia dan jahat pada Matius 24:45-51. Rasul Paulus juga mengingatkan kita agar melakukan segala sesuatu seperti untuk Tuhan dan bukan untuk manusia (Kol.3: 23).

3. Pelita kita harus tetap menyala. Sungguh menyedihkan gambaran tentang gadis bodoh yang diberikan Tuhan Yesus dalam Matius 25:1-13. Mereka telah lama menanti dan merindukan kedatangan mempelai lakilaki tersebut. Namun pada saat yang dirindukan tersebut tiba, mereka tidak siap menyambutnya, karena pelita mereka tidak menyala. Mereka kekurangan minyak untuk menyalakan pelita tersebut. Konteks perumpamaan tersebut jelas, yaitu mengenai kedatangan Tuhan Yesus kembali di akhir zaman. Karena itu, kita juga jangan sampai seperti gadis bodoh tersebut. Kita harus seperti gadis yang bijaksana tersebut yang pe-litanya tetap menyala. Alkitab menegaskan, "Janganlah hendaknya kerajinanmu kendor, biarlah rohmu menyala-nyala dan layanilah Tuhan" (Ro.12:11). Karena itu, kita harus terus menerus memelihara hubungan pribadi kita dengan-Nya melalui doa dan pembacaan firman Tuhan tiaptiap hari, serta tekun bersekutu dan beribadah dengan motivasi yang benar.

4. Mengembangkan talenta yang diberikan Tuhan. Dalam perumpamaan Tuhan Yesus tentang talenta dalam Matius 25:14-30, jelas dituntut kesetiaan. Sangat penting ditegaskan bahwa masalahnya bukanlah berapa banyak talenta yang kita miliki dan berapa banyak yang dihasilkan ketika mengembangkannya, tetapi bagaimana sikap kita terhadap talenta tersebut. Kiranya dalam anugerah-Nya kita juga boleh mendengar pujian Tuhan Yesus berikut: "Baik sekali perbuatanmu itu, hai hambaKu yang baik dan setia; engkau telah setia dalam perkara kecil, aku akan memberikan kepadamu tanggung jawab dalam perkara yang besar. Masuklah dan turutlah dalam kebahagiaan tuanmu" (Mat. 25:21). ${ }^{3 /}$

5. Keempat hal tersebut di atas perlu mendapat penekanan dalam pengajaran PAK di sekolah untuk mengantar siswa tiba pada satu titik

\footnotetext{
${ }^{37}$ Bnd. Mangapul Sagala, Akhir Zaman; diakses 29 maret 2010; tersedia di http://www.sarapanpagi.org/akhir-zaman-akhir-zaman-vt255.html didownload 29 Maret 2010
} 
puncak pemahaman dan penghayatan bahwa ketika Tuhan Yesus datang untuk yang kedua kalinya kelak, Ia akan menjadi Hakim yang mengadili semua umat manusia. Penegasan ini diharapkan dapat mempersiapkan diri siswa sedini mungkin untuk meyambut kedatanganNya yang kedua kali sehingga dalam diri siswa dan orang percaya umumnya sungguhsungguh menyadari dan memahami bahwa apa yang kita perbuat di dunia ini, kelak akan kita pertanggungjawabkan masing-masing di hadapan Tuhan Yesus. Doktrin tentang eskatologi dalam Perjanjian Baru harus ditanamkan dalam diri siswa di sekolah sedini mungkin supaya mereka belajar untuk hidup berdasarkan kehendak Allah dan menjauhi atau meninggalkan bentuk-bentuk kehidupan yang tidak berkenan kepada Allah.

\section{Kesimpulan}

\section{PENUTUP}

Berdasarkan pemaparan singkat di atas, maka penulis menyimpulan bahwa: Pertama, Pengajaran tentang eskatologi dalam PAK di sekolah khususnya di SD dan SMP sangat penting tetapi masih sangat kurang mendapat perhatian. Hal itu jelas bila kita memerhatikan kurikulum PAK yang tidak mencantumkan topik eskatologi sebagai salah satu materi pokok. Kedua, Dalam rangka pengimplementasian topik eskatologi dalam pengajaran PAK di sekolah, maka hal-hal yang harus ditekankan adalah nasihat untuk berjaga-jaga, bekerja dengan setia, pelita kita harus tetap menyala dan mengembangkan talenta yang diberikan oleh Tuhan.

\section{Saran-Saran}

Berdasarkan kesimpulan di atas, maka penulis memberikan saransaran sebagai berikut: Pertama, Hendaknya guru PAK jeli dan tanggap melihat peluang untuk memasukkan topik eskatologi ini dalam pengajaran PAK di sekolah karena KTSP memberikan peluang untuk hal itu dengan menyisipkannya pada SK dan KD yang terkait. Kedua, Dalam pengajaran tentang topik eskatologi kepada siswa di sekolah, hendaknya guru PAK benar-benar menekankan: nasihat untuk berjaga-jaga; bekerja dengan setia; pelita kita harus tetap menyala; dan mengembangkan talenta yang diberikan oleh Tuhan sebagai persiapan untuk menyambut kedatangan Tuhan Yesus yang kedua kalinya. Sekian dan terima kasih. 


\section{KEPUSTAKAAN}

Buku

Beyer, Ulrich, Garis-Garis Besar Eskatologi Dalam Perjanjian Baru. Jakarta: BPK Gunung Mulia, 2001.

Hadiwijono, Harun, Iman Kristen. Jakarta: BPK Gunung Mulia, 2007, Cet. ke18.

, Harun, Inilah Sahadatku. Jakarta: BPK Gunung Mulia, 1995.

Homrighausen, E. G. dan I. H. Enklaar, Pendidikan Agama Kristen. Jakarta: BPK Gunung Mulia, 2004.

Hutabarat, Oditha dan Wiwik Estiawan, Kurikulum Pendidikan Agama Kristen Berbasis Kompetensi Sekolah Dasar. Jakarta: Bagian Proyek Peningkatan Wawasan Kependidikan Guru Agama Ditjen Dikdasmen Depdiknas, 2003.

Palinggi', J. K., wawancara oleh penulis, Makassar, 30 Maret 2010.

Posumah-Santosa, Jedida T., Pendidikan Agama Kristen di Sekolah, dalam Andar Ismail (Peny.), Ajarlah Mereka Melakukan. Jakarta: BPK Gunung Mulia, 2004.

Sidjabat, B. Samuel, Strategi Pendidikan Kristen. Yogyakarta: Andi Offset, 1994.

Soedarmo, R., Ikhtisar Dogmatika. Jakarta: BPK Gunung Mulia, 2001

Willmington, H. L., Eskatologi. Malang: Gandum Mas, 1997.

\section{Internet}

Eskatologi-2, sarapanpagi.com; diakses 29 Maret 2010; tersedia di http://www.Sarapanpagi.org/eskatologi-vfll.html.

Sagala, Mangapul, Akhir Zaman; diakses 29 Maret 2010; tersedia di http://www.sarapanpagi.org/akhir-zaman-akhir-zaman-vt255.html 